\title{
FAILURE DATA EVALUATION FOR STRUCTURAL ELEMENTS
}

\author{
Vivien Sipkás \\ PhD student, University of Miskolc, Institute of Machine and Product Design \\ 3515 Miskolc, Miskolc-Egyetemváros, e-mail: machsv@uni-miskolc.hu \\ Gabriella Vadászné Bognár \\ professor, University of Miskolc, Institute of Machine and Product Design \\ 3515 Miskolc, Miskolc-Egyetemváros, e-mail: v.bognar.gabriella@uni-miskolc.hu
}

\begin{abstract}
The aim of this paper is to systematically analyze test results performed on the lifetime of micro switches and to give a characterization of the lifetime of each product with changes in mean, standard deviation. Failure data are compared using the Weibull distribution We summarize the factorial experimental design of the tests and the experimental models of the response function. Our goal is to develop a life prediction method and to predict the reliability of products in engineering practice.
\end{abstract}

Keywords: Weibull distribution, micro switches, density function, lifetime tests, Weibull-curves

\section{Introduction}

The consumer society demands more and more reliable, longer-lasting and technologically flawless products. High expectations demands require carefully designed reliability lifetime tests. A good method is to use accelerated lifetime tests, which have an advantage of being able to determine statistically reliable lifetime data in less time. Accelerated life tests are characterized by an increased degree of lifetime, such as increased frequency of use, change in speed, increase and decrease in load levels, and environmental effects. The product components to be tested, micro switches, are in the circuits of basic electrical equipment in many areas of industry. These units come in a variety of sizes, types, designs for our everyday environments, such as household appliances, vehicles and power tools.

Our research with accelerated lifetime tests aims to develop a lifetime forecasting methodology that allows forecasting in engineering practice and describes the lifetime, reliability, and potential maintenance time of structural elements. We take into account the products' own operating, conditions and failure processes. Several types of micro switches were subjected to a lifetime test with multiple environmental and operational effects, such as two humidities and two switching times. Based on these studies, we want to achieve the development of a lifetime estimation model.

Several factors, such as temperature, humidity, and switching time, can affect the proper operation of products, damage to internal components, such as wear and tear on contact surfaces.

One of the most common problems of a micro switch is the deformation due to high temperature. There are several reasons for this problem, for example overheats due to overload and over switching.

When the circuit is closed and interrupted, an arc is created. The materials migration is the consequence of this phenomena, due to the heat generation and the increase of the temporary resistance. It results the overheating of the pre-assembled components such as springs.

A further breakdown when the current flow through the switch is greater than the allowed value, or in case of short circuit, the spring can deform, losing its elasticity and ceasing its original function. Therefore, the machine cannot be switched off or switched on. There may be a loss of material caused 
by a static discharge through the contacts. Due to electrical, thermal and mechanical stresses, the contact can break over a certain number of switches due to clamping.

Another typical failure problem is the wear of the micro switch's switch-button, which could be the result of poor construction design, inadequate choice of parts, manufacturing defects, but also of the lateral compression loads in operation and high switching numbers. As a result of all these failures, the component may be damaged and broken [7].

The aim of this paper is to present the test results on micro switches and to characterize the lifetime of each product with changes in mean, standard deviation, and density functions of Weibull distribution.

\section{The tests}

To test the effects of the conditions, we assembled a test workbench on which four different types of switches are tested simultaneously. The equipment is operated by means of a PLC program, which allows us to monitor the number of connections that actually take place on the units. Different humidity levels and switching times can be set on the device $[8,11,12]$. The subject of the study is how many connections the products fail after. A micro switch is considered faulty if it can no longer perform the switching function. During the tests, we can compare the lifetime data of the products operated at different levels.

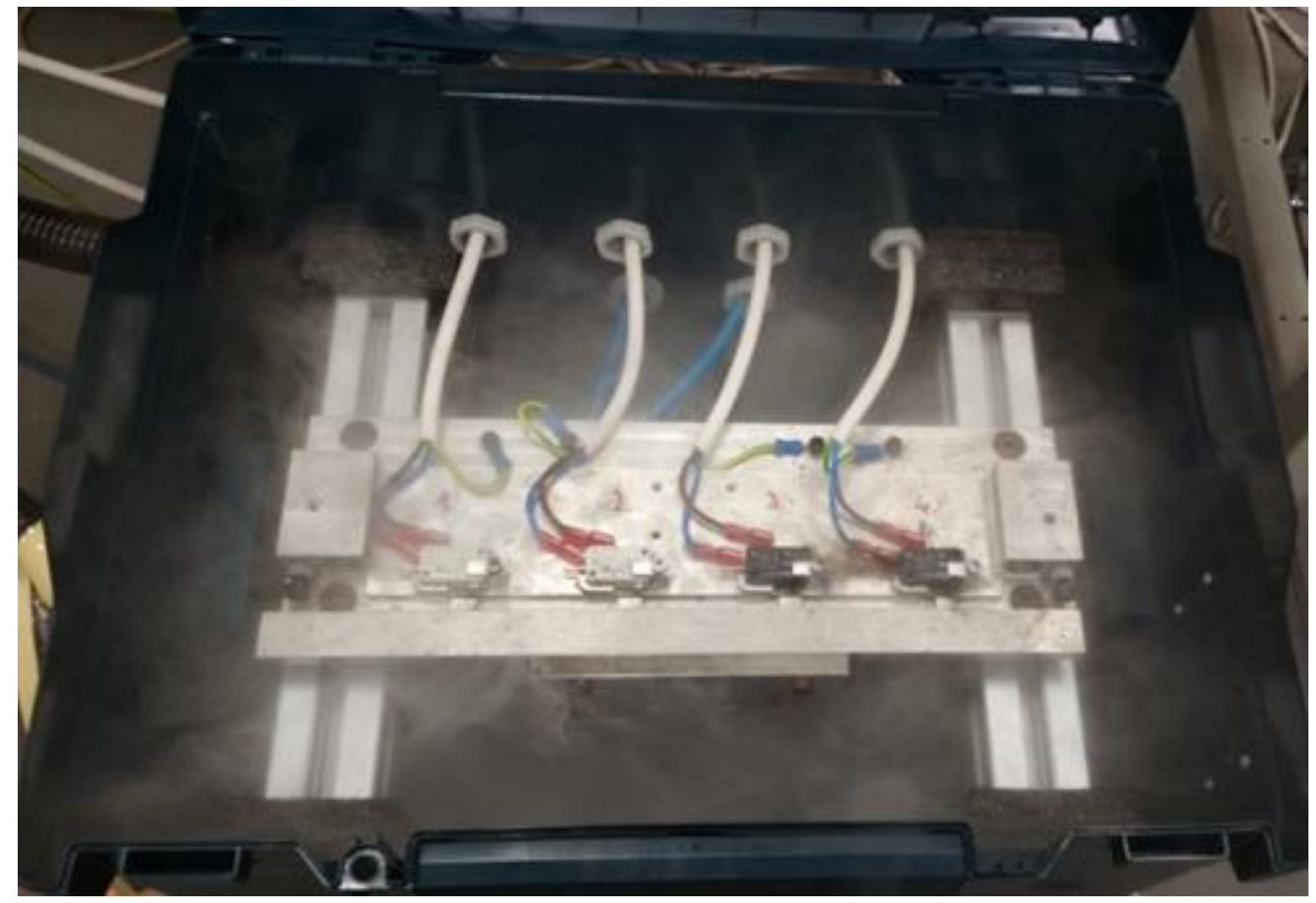

Figure 1. Testing at $80 \%$ humidity

In papers [13-14], all experimental possibilities are summarized using an experimental matrix. In our experiment, we determined the factors and levels as a function of the micro switch types, switching time, 
and humidity examined. Based on the data, we determine the response surface functions for linear and nonlinear cases, giving the factors and failure cycle numbers. A total of 4 samples types were tested during the lifetime tests, with two switching times at two humidity levels. These failure data are presented in detail in the following section with diagrams.

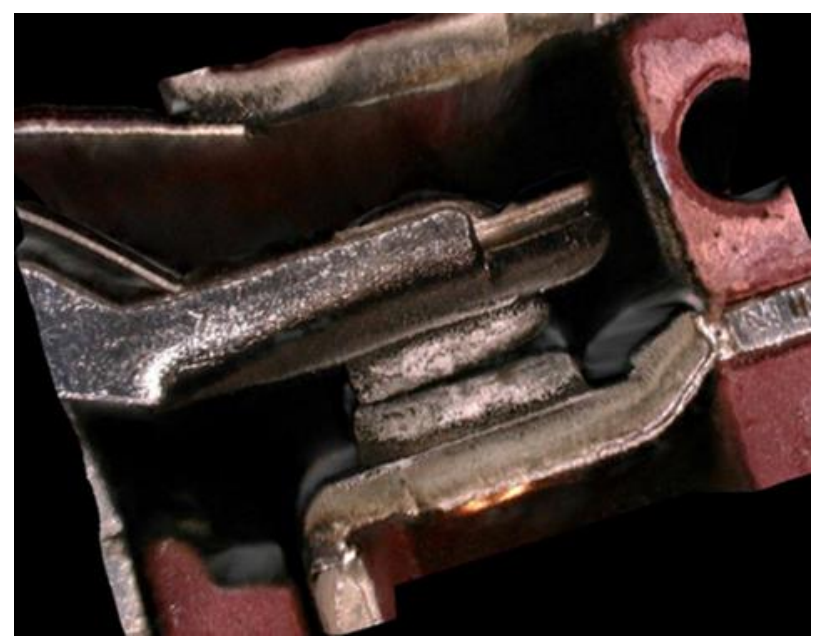

Figure 2. Contact surfaces of micro switch

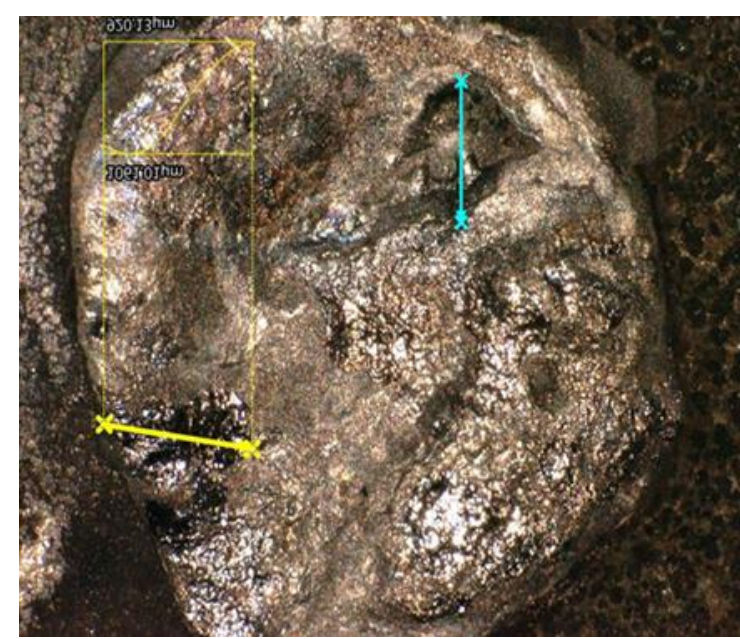

Figure 3. The burned contact surface of the micro switch

The relationships used in papers [13-14] as to determine the $b_{i}$-coefficients, linear, and nonlinear response functions of switches for switch D1 are shown in Table 1.

Table 1. The response function for two factor with the linear model and non-linear model micro switch D1 [13-14]

\begin{tabular}{|c|ccc|c|}
\hline $\begin{array}{c}\text { Determina- } \\
\text { tion of } \mathrm{b}_{\mathrm{i}} \text { co- } \\
\text { efficients for } \\
4 \text { factors }\end{array}$ & $b_{i}=\frac{1}{4} \sum_{i=1}^{4} x_{j i} \cdot y_{i},(j=0,1,2) \quad(1) \quad$ and \\
\hline $\begin{array}{c}\text { Linear model } \\
\text { response func- } \\
\text { tion }\end{array}$ & $y=b_{0}+b_{1} \cdot x_{1}+b_{2} \cdot x_{2}+\ldots+b_{N} \cdot x_{N}$ & (3) & $b_{12}=\frac{1}{4} \sum_{i=1}^{4} x_{1 i} x_{2 i} \cdot y_{i}$, (2) \\
& $y=141402,5-12155,5 \cdot x_{1}-13265 \cdot x_{2}$ & $(4)$ & $\begin{array}{c}\text { Figure 4. The response } \\
\text { function for two factor } \\
\text { with the linear model }\end{array}$ \\
\hline
\end{tabular}




\begin{tabular}{|c|c|c|}
\hline $\begin{array}{c}\text { Nonlinear } \\
\text { model re- } \\
\text { sponse func- } \\
\text { tion }\end{array}$ & $\hat{\mathrm{y}}=b_{0}+b_{1} \cdot x_{1}+b_{2} \cdot x_{2}+b_{12} \cdot x_{1} \cdot x_{2} \cdot \quad(5)$ & $\begin{array}{c}\text { Figure 5. The response } \\
\text { function for two factor } \\
\text { with the non- linear } \\
\text { model }\end{array}$ \\
\hline
\end{tabular}

Table 2. Two factor full experimental matrix for type D1 switch [13-14]

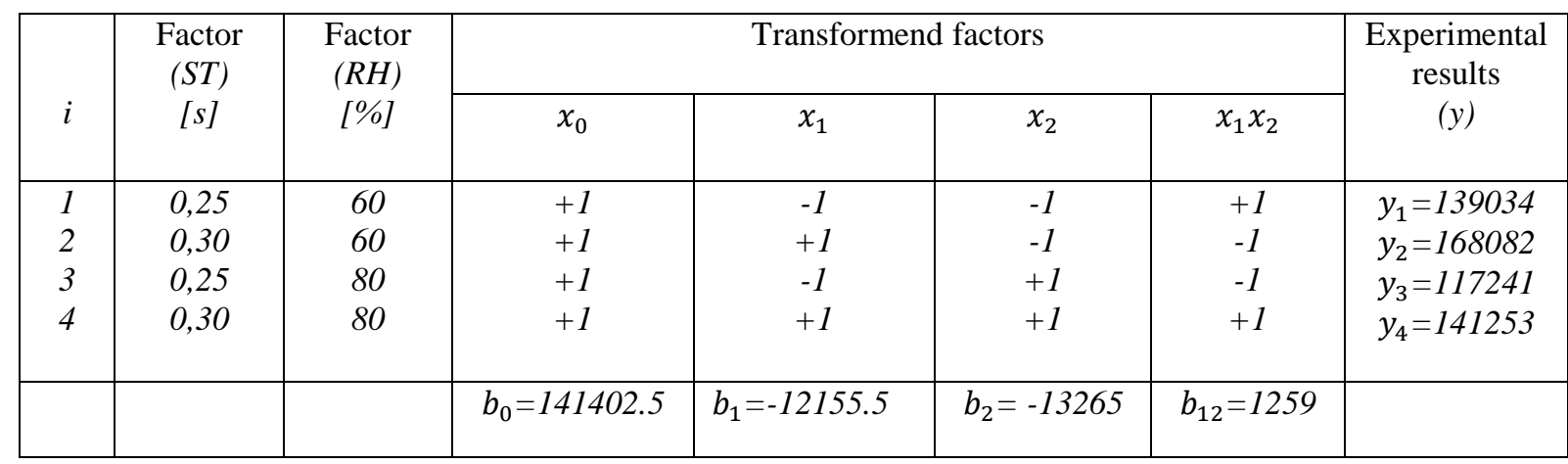

\section{Failure data and their illustration with diagrams}

In our experiments we tested 4 types of micro switches, which were marked D1, D2, K1 and K2. 10 of each type were tested with 4 settings. So we have a total of 160 ruined samples.

The 4 settings are as follows:

1. 0.25 s switching time (switch on: $0.25 s$ - switch off: $0.25 s$ ) and $60 \%$ humidity (40 samples),

2. 0.25 s switching time (switch on: 0.25 s - switch off: 0.25 s) and $80 \%$ humidity (40 samples),

3. $0.30 \mathrm{~s}$ switching time (switch on: 0.30 s - switch off: 0.30 s) and $60 \%$ humidity (40 samples),

4. 0.30 s switching time (switch on: 0.30 s - switch off: 0.30 s) and $80 \%$ humidity (40 samples).

The measured data are shown in Figure 6. and Figure 7.

The failure micro switch data was plotted with the switching number as the switching time / humidity varied. The measurement results of the 4 settings outlined in the previous section are presented [15].

Figure 6 . shows the results obtained with $80 \%$ humidity setting and switching times of $0.25 \mathrm{~s}$ or $0.30 \mathrm{~s}$. We compared the failure data obtained with two different switching times but the same humidity setting.

Figure 7. shows the data tested at a switching time of $0.25 \mathrm{~s}$ and a humidity of $60 \%$ and $80 \%$, respectively. The diagram shows the failure cycle numbers obtained at two different humidities but the same switching time setting. 


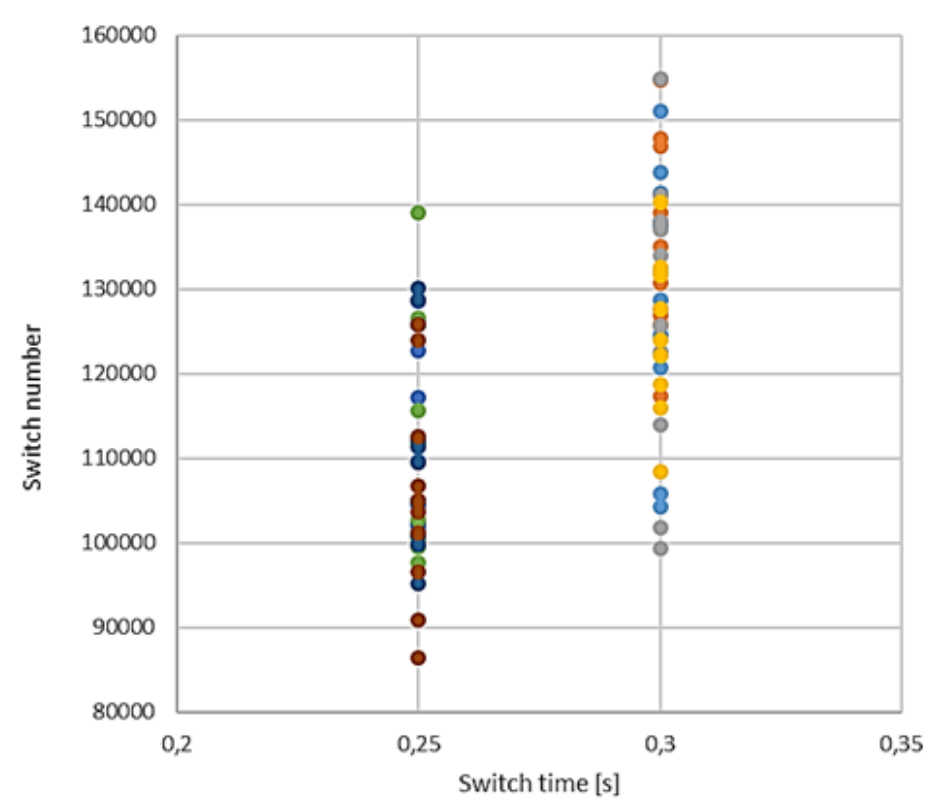

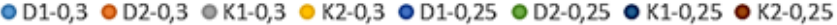

Figure 6. Failure data with $80 \%$ humidity

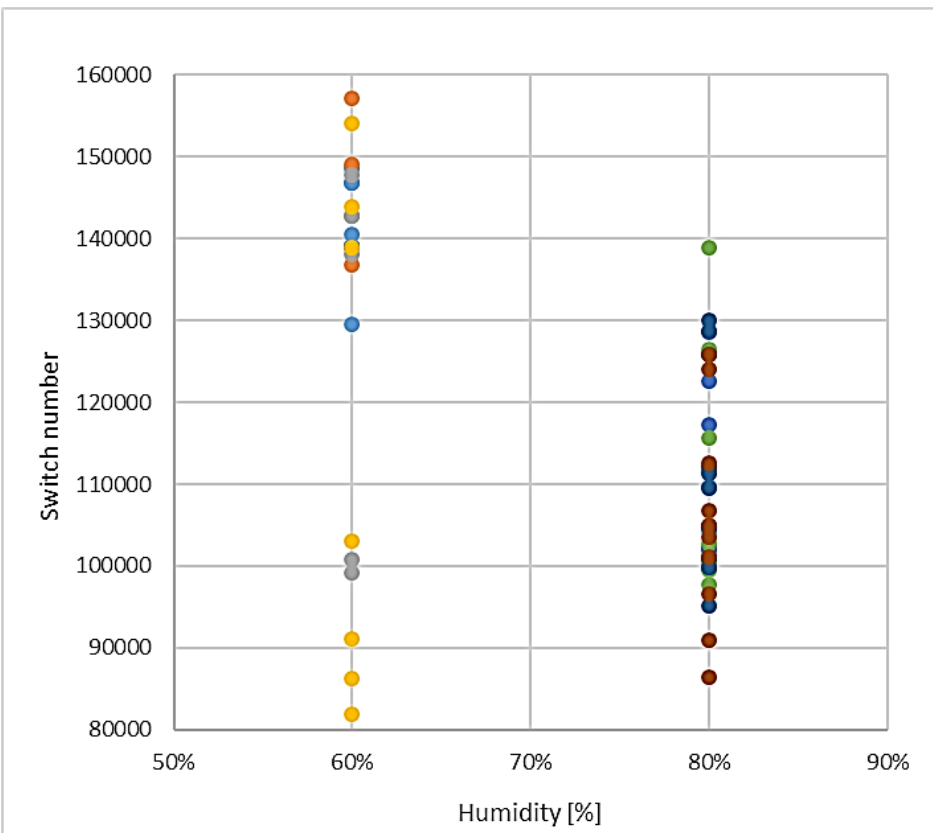

o $\mathrm{D} 1-60 \%$ ○ $\mathrm{D} 2-60 \%$ ○ K1-60\% ○ K2-60\% ○ D1-80\% ○ $\mathrm{D} 2-80 \%$ ○ $\mathrm{K} 1-80 \%$ ○ K2-80\%

Figure 7. Failure data with 0.25 s switch time 
The diagrams below show the mean and standard deviation of the data obtained at the switching time and humidity levels of the different switch types.

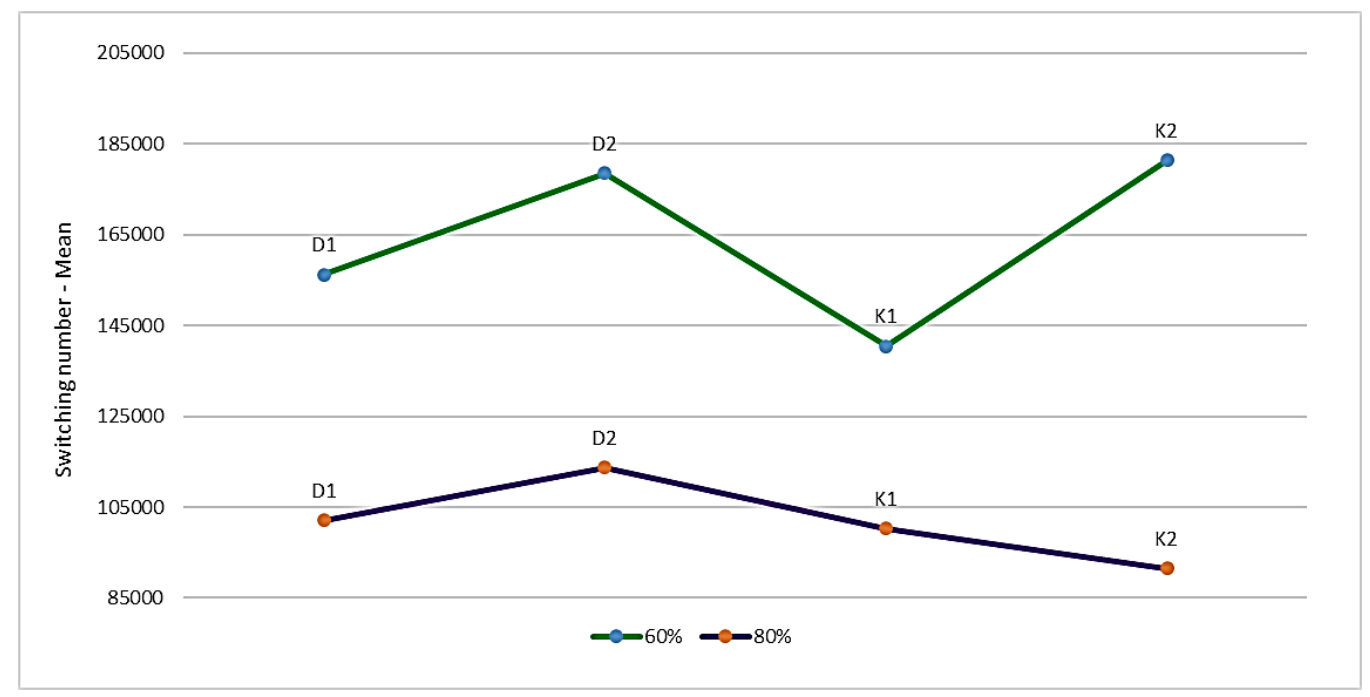

Figure 8. Mean of failure data-0.25s (60\% - 80\%)

The average and standard deviation of the 10 failure data were determined for each switch type (D1, $\mathrm{D} 2, \mathrm{~K} 1, \mathrm{~K} 2$ ). Figure 8. shows the averages calculated from the results of the samples tested with the 0.25 s switching time setting with two humidity level settings. At $60 \%$ humidity, the mean of switch K1 is the lowest and that of switch K2 the highest and in case of $80 \%$ humidity, the mean of switch K2 is the lowest and that of switch D2 the highest.

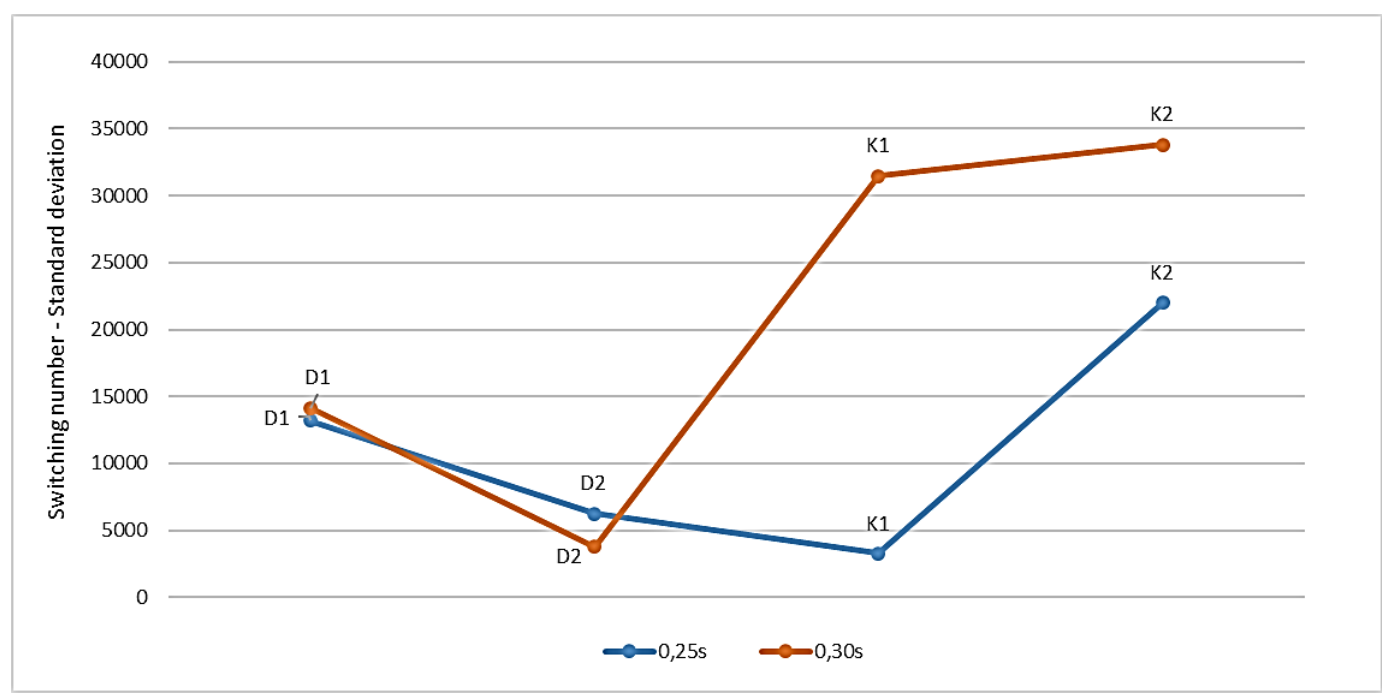

Figure 9. Standard deviation of failure data $-60 \%(0.25 s-0.30 s)$

Figure 9. shows the standard deviations calculated from the results with $60 \%$ humidity setting, switching times of $0.25 \mathrm{~s}$ and $0.30 \mathrm{~s}$. At a setting of $0.25 \mathrm{~s}$, the standard deviation of switch $\mathrm{K} 1$ is the 
lowest and that of switch type $\mathrm{K} 2$ is the largest. and at 0.30 s, D2 is the lowest and the standard deviation of $\mathrm{K} 2$ is also the largest.

\section{Application of Weibull distribution for measurement data}

During the failure analysis of the micro switches, the results of the failure tests and the effect of the failure processes on the lifetime of the products are analyzed using the Weibull distribution.

The general three-parameter Weibull distribution function is of the form [1-8]:

$$
F(t)=\left\{\begin{array}{r}
1-\exp \left[-\frac{(t-\gamma)^{\beta}}{\alpha}\right], \text { if } t \geq \gamma, \\
0, \quad \text { if } t<\gamma .
\end{array}\right.
$$

The function $F(t)$ gives the probability of failure during the actual operating time the scrap rate. In formula (7), $t$ is the statistical variable,

$\alpha>0$ scale parameter,

$\beta>0$ shape parameter,

$\gamma \geq 0$ is a position parameter which is taken as 0 in our cases.

Figures 10-11. shows the effects of the scale parameter $(\alpha)$ and the shape parameter $(\beta)$ on the Weibull distribution density function. In the case when $\alpha$ is larger, the shape of the density function will be wider. If, on the other hand, $\beta$ is larger, then the shape of the density function is higher.
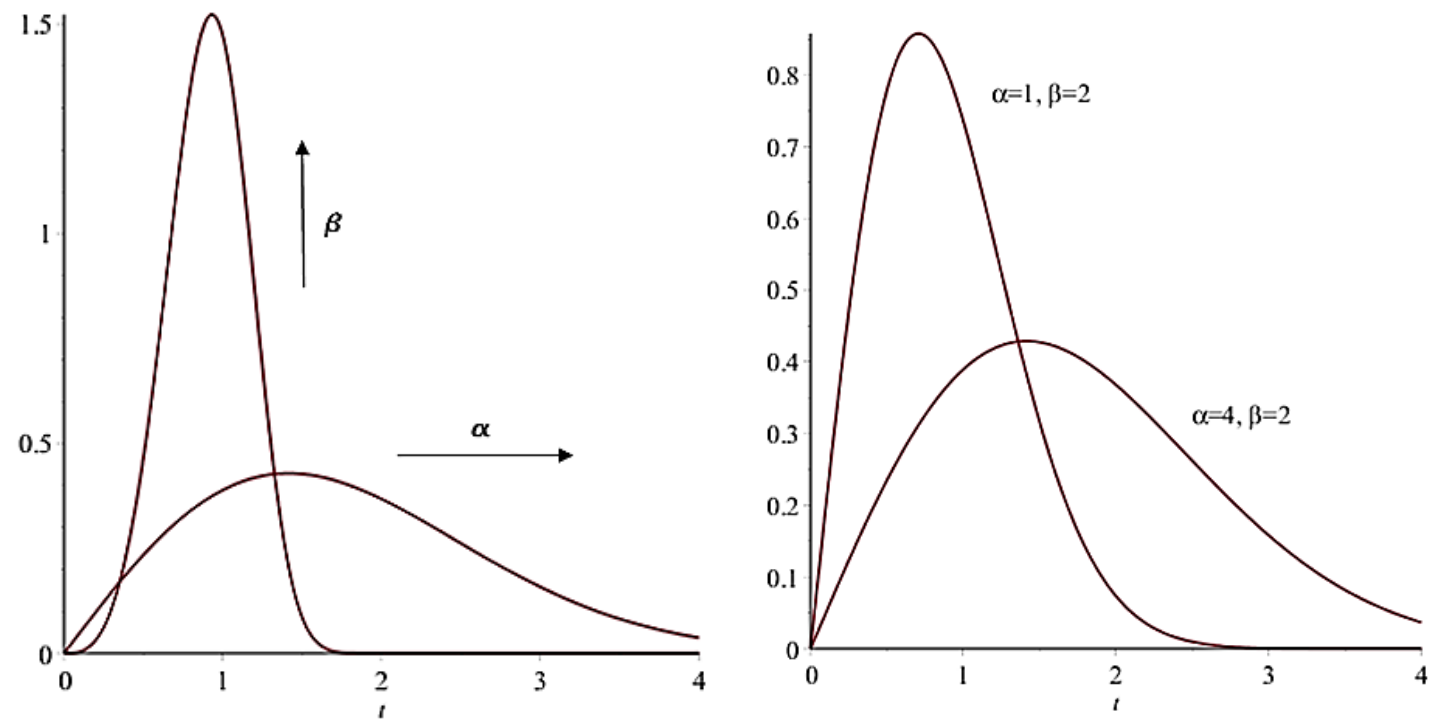

Figure 10-11. Density function of the Weibull distribution

Based on the lifetime tests, the density functions for the lifetime of the micro switches were plotted from the failure cycle numbers using the Distribution fitter module of Matlab software (see Figures 1213).

Tables 3-4. give the calculated values between which the estimated and standard error values of the scale parameter $(\alpha)$ and the shape parameter $(\beta)$ can be observed for each type. Table 3 shows only the 
values calculated from the data measured with a switching time of $0.25 \mathrm{~s}$ and the two types of humidity setting.

Table 3. Values $0.25 \mathrm{~s}$ and $0.30 \mathrm{~s}$ switching time

\begin{tabular}{|c|c|c|c|c|c|}
\hline $\begin{array}{l}\text { Values calculated by } \\
\text { Matlab }\end{array}$ & D1 & D2 & K1 & $\mathrm{K} 2$ & $\begin{array}{l}\text { Switching } \\
\text { time } \\
\text { Humidity } \\
\%\end{array}$ \\
\hline Log. likelihood & -106.951 & -116.053 & -119.429 & -119.975 & \multirow{8}{*}{$\begin{array}{l}0.25 \mathrm{~s} \\
60 \%\end{array}$} \\
\hline Domain & $0<\mathrm{y}<\operatorname{Inf}$ & $0<\mathrm{y}<\operatorname{Inf}$ & $0<\mathrm{y}<\operatorname{Inf}$ & $0<\mathrm{y}<\operatorname{Inf}$ & \\
\hline Mean & 142561 & 174560 & 156205 & 133136 & \\
\hline Variance & $1.546 \mathrm{e}+08$ & $8.1230 \mathrm{e}+08$ & $1.60259 \mathrm{e}+09$ & $1.38999 \mathrm{e}+09$ & \\
\hline$\alpha$ (estimate) & 147951 & 186311 & 171349 & 146867 & \\
\hline$\beta$ (estimate) & 140257 & 7,21932 & 4,41987 & 4,00806 & \\
\hline$\alpha$ (std.error) & 3555.03 & 8663.35 & 12965.5 & 12230 & \\
\hline$\beta$ (std. error) & 3.05178 & 1.69008 & 1.08977 & 1.014260 & \\
\hline Log. likelihood & -107.062 & -110.17 & -108.475 & -108.729 & \multirow{8}{*}{$0.25 \mathrm{~s}$} \\
\hline Domain & $0<\mathrm{y}<\operatorname{Inf}$ & $0<\mathrm{y}<\operatorname{Inf}$ & $0<\mathrm{y}<\operatorname{Inf}$ & $0<\mathrm{y}<\operatorname{Inf}$ & \\
\hline Mean & 108689 & 108856 & 111640 & 105024 & \\
\hline Variance & $1.44209 \mathrm{e}+08$ & $2.6862 \mathrm{e}+08$ & $1.77014 \mathrm{e}+08$ & $1.87361 \mathrm{e}+08$ & \\
\hline$\alpha$ (estimate) & 113825 & 115679 & 117300 & 110803 & \\
\hline$\beta$ (estimate) & 10.9422 & 7.87562 & 10.101 & 9.18599 & \\
\hline$\alpha$ (std.error) & 3501.56 & 4949.79 & 3895.59 & 4045.71 & \\
\hline$\beta$ (std. error) & 2.53632 & 1.7752 & 2.46472 & 2.19941 & \\
\hline
\end{tabular}

Table 4. Values $0.25 \mathrm{~s}$ and $0.30 \mathrm{~s}$ switching time

\begin{tabular}{|c|c|c|c|c|c|}
\hline $\begin{array}{l}\text { Values calculated by } \\
\text { Matlab }\end{array}$ & D1 & D2 & K1 & K2 & \\
\hline Log. likelihood & -111.834 & -111.333 & -118.561 & -115.691 & \multirow{8}{*}{$\begin{array}{c}0.30 \mathrm{~s} \\
60 \%\end{array}$} \\
\hline Domain & $0<\mathrm{y}<\operatorname{Inf}$ & $0<\mathrm{y}<\operatorname{Inf}$ & $0<\mathrm{y}<\operatorname{Inf}$ & $0<\mathrm{y}<\operatorname{Inf}$ & \\
\hline Mean & 151303 & 188353 & 172365 & 183622 & \\
\hline Variance & $3.22653 \mathrm{e}+08$ & $3.060045 \mathrm{e}+08$ & $1.14682 \mathrm{e}+09$ & $6.61174 \mathrm{e}+08$ & \\
\hline$\alpha$ (estimate) & 158945 & 195913 & 185950 & 194407 & \\
\hline$\beta$ (estimate) & 10.1419 & 13.1326 & 5.91063 & 8.50977 & \\
\hline$\alpha$ (std.error) & 5235.54 & 4986.56 & 10464.1 & 7601.91 & \\
\hline$\beta$ (std. error) & 2.60717 & 3.27806 & 1.52868 & 2.2295 & \\
\hline Log. likelihood & -109.903 & -107.895 & -111.396 & -105.144 & \multirow{8}{*}{$\begin{array}{l}0.30 \mathrm{~s} \\
80 \%\end{array}$} \\
\hline Domain & $0<\mathrm{y}<\operatorname{Inf}$ & $0<\mathrm{y}<\operatorname{Inf}$ & $0<\mathrm{y}<\operatorname{Inf}$ & $0<\mathrm{y}<\operatorname{Inf}$ & \\
\hline Mean & 129779 & 134940 & 126842 & 125236 & \\
\hline Variance & $2.13386 e+08$ & $1.62373 \mathrm{e}+08$ & $2.97214 \mathrm{e}+08$ & $9.12767 \mathrm{e}+07$ & \\
\hline$\alpha$ (estimate) & 136019 & 140442 & 134094 & 129402 & \\
\hline$\beta$ (estimate) & 10.7296 & 12.9066 & 8.78488 & 16.1263 & \\
\hline$\alpha$ (std.error) & 4217.12 & 3649.35 & 5092.5 & 2681 & \\
\hline$\beta$ (std. error) & 2.76049 & 3.10867 & 2.17941 & 3.94166 & \\
\hline
\end{tabular}

Figures 12-13. show the Weibull density functions plotted from data obtained during lifetime tests of four type of micro switches.

Figure 12. compares the Weibull distributions, the curves were based on the measured data at $0.25 \mathrm{~s}$ switching time, $60 \%$ and $80 \%$ humidity. It can be seen that the density function of switches K2, K1, D1 
and D2 at $80 \%$ humidity has a longer shape, so the lifetime also increases, but the reliability of the products is lower.

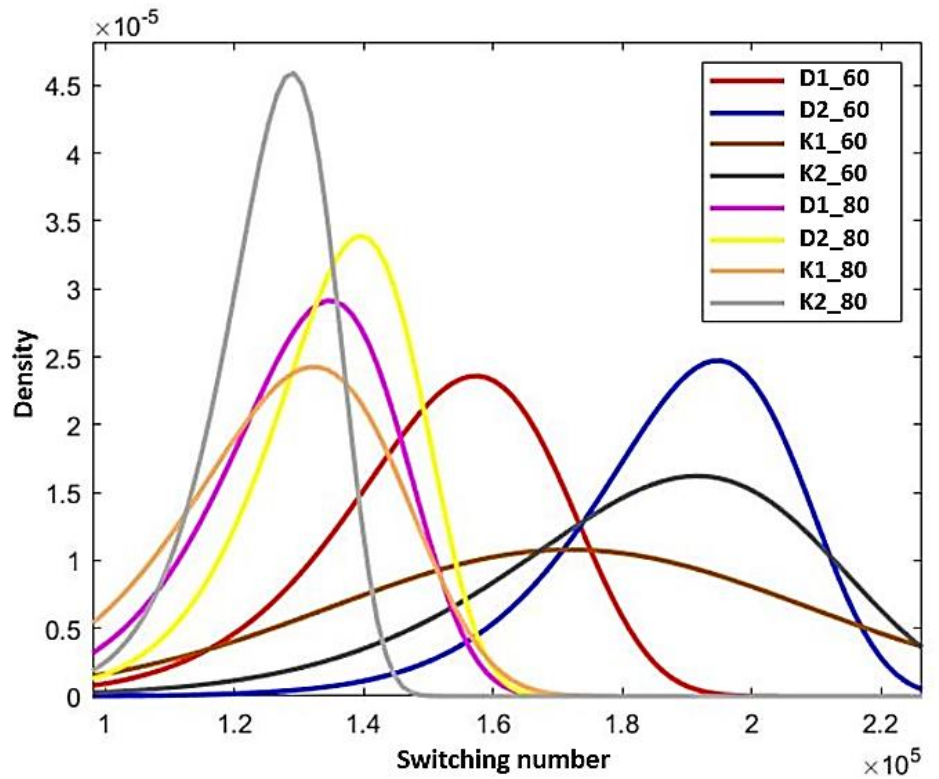

Figure 12. Comparing the density functions: 0.30s switch time as well as $60 \%$ and $80 \%$ humidity

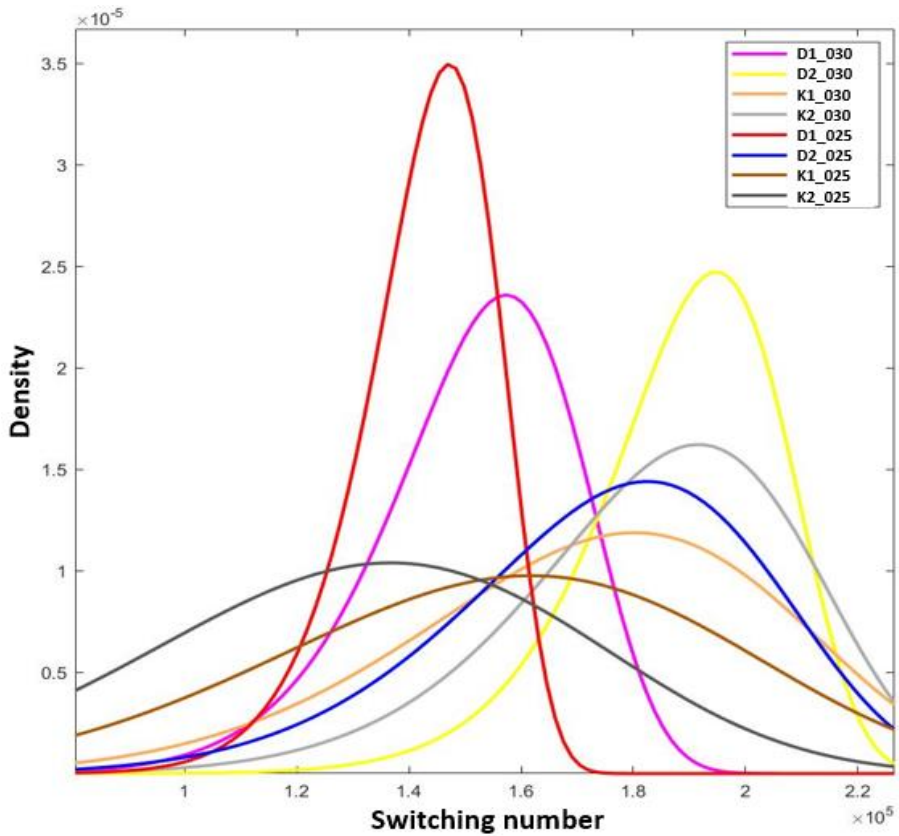

Figure 13. Comparison of density function $60 \%$ humidity as well as $0,25 \mathrm{~s}$ and 0.30s switch time 
Figure 13. shows the curves from the results of measurements performed at the $60 \%$ humidity setting with the two switching time settings. It can be observed that the density functions shifted to the right for all four switch types at $60 \%$ humidity, the lifetime of the tested products increased.

\section{Summary}

Based on the test series, four comparisons were made, with two humidity levels and two switching time settings. We compared the results obtained and illustrated the lifetime data using diagrams. Based on these, we calculated the standard deviation and mean of the failure data from the database data. Furthermore, the failure cycle numbers on the switching time as well as the switching number/ humidity axis were illustrated.

Finally, following the four comparison theories, we also plotted the product lifetime data as a function of the effects of the Weibull distribution scale and shape parameters using Matlab software. We found that if the scale parameter is larger, the products are more reliable but have a shorter lifespan. On the other hand, if the shape parameter is larger, the lifetime also increases, but the reliability of the switches is lower.

Furthermore, comparing the test results obtained, it is found that the maximum lifetime for all four switch types was provided by a switching time of $0.30 \mathrm{~s}$ and a humidity of $60 \%$. The shortest lifetime was $0.25 \mathrm{~s}$ switching time and $80 \%$ humidity.

In the rest of the research, we would also like to compare the results of samples tested with several switch time, thus providing a closer estimate of the product lifetime data.

\section{Acknowledgements}

The research work described in this paper supported by the UNNKP-19-3 New National Excellence Program of the Ministry for Innovation and Technology.

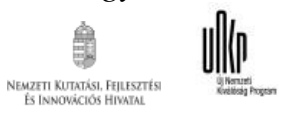

\section{References}

[1] Balogh, A., Dukáti, F., Sallay, L.: Minőség-ellenörzés és megbizhatóság, Müszaki Könyvkiadó, Bp.,1980, ISBN 0-262-04219-3

[2] Finszter, F., Aradi P., Czmerk, A., Németh Z., Wenzelné Gerőfy, K., Halmai A.: Jármüipari tesztelés és jóváhagyás (Date of download:2020.02.21.)

[3] Fridrik, L., Csóka J., Maros, Zs., Orosz, L.: Faktoriális kisérlettervezés I., Nehézipari Müszaki Egyetem, Gépészmérnöki Kar, Miskolc, 1988.

[4] Johanyák, Zs.: Bevezetés a kísérletmódszertanba, Kecskeméti Főiskola, Kecskemét, 2002.

[5] Kemény, S., Deák, A.: Kisérletek tervezése és értékelése, Műszaki Könyvkiadó, 2000.

[6] Meeker, W. Q., Escobar, L. A.: Statistical methods for reliability data, Wiley-Interscience Publication - John Wiley \& Sons, INC, Copyright, 1998, ISBN 978-0-471-14328

[7] Sipkás, V., Vadászné Bognár, G.: The application of accelerated life testing method for micro switches, International Journal of Instrumentation and Measurement, http://www.iaras/journals/ijim,Vol. 3, (2018) pp. 1-5. ISSN 2534-8841

[8] Sipkás, V., Vadászné Bognár, G.: Gyorsitott élettartam vizsgálat alkalmazása mikrokapcsolókra, 2018 Erdélyi Magyar Müszaki Tudományos Társaság (EMT) Gépészeti Szakosztálya által szervezett XXVI. Nemzetközi Gépészeti Konferencia kiadványa, pp. 405-408., ISSN 2068-1267 
[9] Sipkás, V., Vadászné Bognár, G.: Failure prediction models for accelerated life tests, WSEAS Transactions on Circuits and Systems, Vol. 17, (2018) pp. 173-179., E-ISSN 2224-266X

[10] Sipkás, V., Vadászné Bognár, G.: Testing of micro switches for garden tools, International Journal of Engineering and Management Sciences (IJEMS), Vol. 4, No.1, (2019) pp. 206-213. https://doi.org/10.21791/IJEMS

[11] Sipkás,V., Vadászné Bognár, G.: Kerti gépekben alkalmazott mikrokapcsolók élettartam adatainak vizsgálata, Multidiszciplináris Tudományok, Vol. 9, No. 2, (2019) pp. 90-95. https://doi.org/10.35925/j.multi.2019.2.13

[12] Sipkás, V., Vadászné Bognár, G.: Testing accelerated life data of micro switches, Design of Machines and Structures, Vol. 9, No. 2, (2019) pp. 44-50., ISSN 1785-6892

[13] Sipkás, V., Vadászné Bognár, G.: Methods for accelerated life testing of micro switches in vehicles, GÉP folyóirat, Vol. 71, No.3-4, (2020) pp. 72-75., ISSN 0016-8572 https://doi.org/10.35925/j.multi.2020.4.1

[14] Sipkás, V., Vadászné Bognár, G.: Szerkezeti elemek tönkremeneteli analizise, Multidiszciplináris tudományok, Vol. 10. No. 4, (2020), pp. 3-12. https://doi.org/10.35925/j.multi.2020.4.1

[15] Sipkás, V., Vadászné Bognár, G.: Mikrokapcsolók meghibásodási adatainak kiértékelése, Gép journal, Vol. 71. No. 7-8, (2020) pp. 57-60., ISSN 0016-8572 